\title{
Forest Reproductive Material and Conservation of Forest Genetic Resources in Croatia
}

\author{
Davorin Kajba, Ivan Andrić \\ Department of Forest Genetics, Dendrology \& Botany, University of Zagreb, Croatia \\ Email: davorin.kajba@zg.t-com.hr
}

Received 2 January 2015; accepted 21 January 2015; published 26 January 2015

Copyright (C) 2015 by authors and Scientific Research Publishing Inc.

This work is licensed under the Creative Commons Attribution International License (CC BY). http://creativecommons.org/licenses/by/4.0/

(c) (i) Open Access

\section{Abstract}

Conservation of genetic diversity of forest tree species represents the foundation for sustainable forest management and preservation of natural structure of forest stands in Croatia. Diversity of geographical regions in Croatia has generated various ecological conditions and thus diverse forest communities which are directly affected by habitat degradation, various anthropogenic effects like pollution of air and water, excessive use of certain more valuable species of forest trees and by the increasing impact of global climatic changes. The need for conservation of genetic diversity is related to the species pertaining to social broadleaves-the prevailing species in terms of economic utilization as Pedunculate Oak (Quercus robur), Sessile Oak (Quercus petraea) and Common Beech (Fagus sylvatica). Among the conifers Silver Fir (Abies alba) is the most endangered species, with more than $70 \%$ of its population being seriously damaged. Other native coniferous species must be preserved from a decrease in genetic diversity as well. Conservation of the noble broadleaves should encompass a larger number of species from various genera (Fraxinus, Alnus, Ulmus, Prunus, Juglans, Castanea, Sorbus, Acer, Malus, Pyrus, Tilia). These are partially endangered because of their exposure to different pests and diseases, as well as by permanent exploitation due to their technical value. Changes in hydrological conditions of rivers have led difficulties in regeneration of the riparian forests and decreased the genetic variability of European Black and White Poplar in their habitats (Populus nigra, P. alba). In Croatia's Adriatic coastal areas, there is a need for conservation of genetic resources of Dalmatian Black Pine (P. nigra ssp. dalmatica) and Mediterranean Oaks (Quercus ilex, Quercus pubescens). Conservation of genetic diversity of various forest tree species is conducted within the programmes that include in situ and ex situ methods with ensuring quality forest reproductive materials. In Croatia, a total of 125 seed stands have been selected, covering a total area of 3885.53 ha. The ex situ method is implemented by establishment of a total of 50 plots (clonal seed orchards, provenances and progeny trials, clonal archives), covering 114.85 ha. 


\section{Keywords}

\section{Forest Genetic Resources, In Situ and ex Situ Methods, Conifers and Broadleaved Species, Croatia}

\section{Introduction}

The woodland area of the Republic of Croatia (2.67 million ha, covering 47\% of the country's continental region) has a total of 260 indigenous woody species, 50\% of which pertain to the forest ecosystem. Among these, 60 species constitute the economic resources of Croatian forests, while several hundred other species supplement forest ecosystem, thus complementing its biodiversity. Forests are the most valuable natural resources in Croatia and $80 \%$ is high stocked state forests (about 2 mill ha), while the remaining $18 \%$ is private owned (about 400000 ha) and are comprised of various groups of unstocked forest land (mostly degradated forests). It should be pointed out that Croatia is one of the few countries to have managed to preserve its natural forests, 95\% of forests are naturally or semi-naturally regenerated by silvicultural management. Croatia now has one of the largest FSC certified forest areas in Europe (Forest Stewardship Council, 2012) and forest land belongs to the state and it's managed by Croatian Forest Co. Significant changes are the consequence of the new legislative and institutional framework defined by the adoption of the National Forestry Strategy and Policy (2003), enactment of the Forest Law (2005, 2006, 2008) and the Act on Forest Reproductive Material (2009) and the Chamber of Forestry and Wood technology Engineers established in 2005. Ministry of Agriculture is responsible of designing and implementing the forestry policy and in the past years lots of regulations were done according to the EU directives (Council Directive 1999/105/EC, 1999).

Conservation of genetic diversity in forest trees represents maintenance of the evolutionary adaptation potential of a particular species, its forest community and the entire forest ecosystem. For the purpose of conservation of forest genetic resources, the existing genetic variability and its adaptability to processes of natural evolution and forest tree breeding must be preserved and the knowledge and ways of identification of individuals tolerant to certain diseases and pests improved. That way, a decline in genetic resources of the endangered species would be decreased. The research will be supplemented with data including species inventories, legislation, practical use, coordination on national and paneuropean levels, together with promotion of public awareness on the importance of conservation of the endangered species in forest ecosystems (Koskela et al., 2007).

Conservation of genetic diversity of various forest tree species is conducted through programes employing in situ and ex situ methods. Conservation of native species by the in situ method is based upon a status quo concept of protection of natural conditions in local habitats with optimal allelic gene frequency having been attained, ensuring survival and reproduction in a given environment. Furthermore, this means that the local populations and certain species of forest trees show best resistance and adaptability to stressful environmental conditions, as well as to pests and diseases. Studies conducted on conservation of genetic diversity include necessary knowledge of the minimum viable population (MVP) which is necessary for the population's relatively safe survival in terms of genetic, demographic, environmental and other factors (Geburek \& Turok, 2005). In terms of size and type of a distribution range of a species (continuous and discontinuous distribution, genetic drift, etc.), it is necessary to determine the number of subpopulations and individuals that will successfully represent, incorporate and preserve the complete variability of a particular species (Eriksson et al., 2013). Conservation by the in situ method (Table 1) is used for the populations protected as special objects of biological and environmental diversity, as well as for natural forest stands that are excluded from regular management (e.g. seed stands).

Because of a large number and diverse characteristics of the endangered species (some of which are more widely distributed, while others only rarely occur in the forest ecosystems, or play multiple roles in terms of both ecology and economy), research on their conservation should be conducted in a separate manner. The prerogative is to ensure minimal requirements in terms of gene conservation of a particular species that could be rendered suitable or adapted for application (depending on the condition and situation of each particular species). This comprises ecology of the species and aims directed towards conservation of its entire gene pool, together with the principles and methods, definitions of the ecogeographical zones (seed zones), inventory of the species genetic resources, determination of the number of populations, as well as individuals needed for conservation. Moreover, silvicultural methods adjusted for protected natural stands are to be established, as well as the impact of human influence on the endangered forest tree species populations. 
Table 1. Conservation of forest genetic resources by in situ method (seed stands in Croatia).

\begin{tabular}{|c|c|c|}
\hline Species & No. & Total area (ha) \\
\hline \multicolumn{3}{|c|}{ Conifers } \\
\hline Abies alba & 14 & 296.55 \\
\hline Picea abies & 11 & 170.59 \\
\hline Pinus brutia & 2 & 13.29 \\
\hline Pinus nigra & 5 & 35.70 \\
\hline Pinus nigra var. corsicana & 1 & 11.30 \\
\hline Pinus sylvestris & 4 & 48.32 \\
\hline Pseudotsuga menziesii & 1 & 0.27 \\
\hline \multicolumn{3}{|c|}{ Social broadleaved species } \\
\hline Fagus sylvatica & 13 & 475.80 \\
\hline Quercus ilex & 1 & 15.47 \\
\hline Quercus petraea & 9 & 430.34 \\
\hline Quercus pubescens & 1 & 43.03 \\
\hline Quercus robur & 33 & 1767.07 \\
\hline Quercus robur var. tardiflora & 5 & 94.18 \\
\hline \multicolumn{3}{|c|}{ Noble hardwoods species } \\
\hline Acer pseudoplatanus & 1 & 21.75 \\
\hline Alnus glutinosa & 4 & 34.51 \\
\hline Carpinus betulus & 2 & 25.95 \\
\hline Castanea sativa & 1 & 22.83 \\
\hline Fraxinus angustifolia & 7 & 157.86 \\
\hline Fraxinus excelsior & 1 & 21.75 \\
\hline Juglans nigra & 3 & 51.62 \\
\hline Tilia tomentosa & 1 & 38.25 \\
\hline Tilia platyphyllos & 1 & 3.07 \\
\hline Ulmus minor & 1 & Group of trees \\
\hline Populus nigra & 1 & 8.06 \\
\hline Prunus avium & 2 & 97.97 \\
\hline Subtotal & 125 & 3885.53 \\
\hline
\end{tabular}

The ex situ method of conservation represents preservation of the forest tree species outside of their natural habitats (Table 2; Figure 1). This method is applied parallel with the in situ method, particularly for species that cannot be conserved, either partially or as whole populations. For that purpose, the ex situ gene banks and experimental plots need to be established, which include provenance and progeny trials, clonal tests, clonal archives, clonal seed orchards, seed, pollen and plant tissue genetic banks.

Conservation of forest genetic resources and sustainable utilization of genetic potentials existing within the forest tree species are highly significant because they reflect the processes of natural regeneration, prospective productivity and sustainability of forests. 
Table 2. Conservation of forest genetic resources by ex situ method.

\begin{tabular}{|c|c|c|c|c|c|}
\hline Species & Labels & Type & No. & Total area (ha) & No. of provenances/families/clones \\
\hline & \multicolumn{5}{|c|}{ Conifers } \\
\hline Abies alba & A & $\mathrm{PF}^{\mathrm{a}}$ & 3 & 3.00 & 29 \\
\hline Picea abies & B & $\mathrm{PF}^{\mathrm{a}}$ & 3 & 12.00 & 43 \\
\hline Pinus sylvestris & $\mathrm{C}$ & $\mathrm{PF}^{\mathrm{a}}$ & 2 & 2.00 & 22 \\
\hline Pinus sylvestris & $\mathrm{D}$ & $\mathrm{CSO}^{\mathrm{b}}$ & 2 & 3.00 & 30 \\
\hline Pinus nigra & E & $\mathrm{PF}^{\mathrm{a}}$ & 1 & 1.00 & 18 \\
\hline Pinus nigra & F & $\mathrm{CSO}^{\mathrm{b}}$ & 2 & 1.50 & 41 \\
\hline Larix europea & G & $\mathrm{PF}^{\mathrm{a}}$ & 5 & 7.00 & 25 \\
\hline \multirow[t]{2}{*}{ Larix europea } & $\mathrm{H}$ & $\mathrm{CSO}^{\mathrm{b}}$ & 2 & 2.50 & 28 \\
\hline & \multicolumn{5}{|c|}{ Social broadlevaed species } \\
\hline Quercus robur & I & $\mathrm{CSO}^{\mathrm{b}}$ & 4 & 47.00 & 150 \\
\hline Quercus robur & $\mathrm{J}$ & $\mathrm{PF}^{\mathrm{a}}$ & 3 & 1.70 & 70 \\
\hline Quercus robur & $\mathrm{K}$ & $\mathrm{PF}^{\mathrm{a}}$ & 3 & 3.85 & 46 \\
\hline \multirow[t]{2}{*}{ Fagus sylvatica } & $\mathrm{L}$ & $\mathrm{PF}^{\mathrm{a}}$ & 2 & 2.00 & 36 \\
\hline & \multicolumn{5}{|c|}{ Noble hardwoods species } \\
\hline Tilia cordata & M & $\mathrm{CSO}^{\mathrm{b}}$ & 1 & 0.72 & 13 \\
\hline Alnus glutinosa & $\mathrm{N}$ & $\mathrm{CSO}^{\mathrm{b}}$ & 2 & 1.70 & 61 \\
\hline Fraxinus angustifolia & $\mathrm{O}$ & $\mathrm{CSO}^{\mathrm{b}}$ & 1 & 3.50 & 56 \\
\hline Fraxinus angustifolia & $\mathrm{P}$ & $\mathrm{PF}^{\mathrm{a}}$ & 4 & 4.50 & 9 \\
\hline Prunus avium & $\mathrm{R}$ & $\mathrm{CSO}^{\mathrm{b}}$ & 1 & 3.00 & 26 \\
\hline Juglans regia & S & $\mathrm{PF}^{\mathrm{a}}$ & 4 & 8.88 & 16 \\
\hline Juglans regia & $\mathrm{T}$ & $\mathrm{CA}^{\mathrm{c}}$ & 2 & 1.00 & 23 \\
\hline \multirow[t]{2}{*}{ Ulmus minor } & $\mathrm{U}$ & $\mathrm{CA}^{\mathrm{c}}$ & 1 & 0.50 & 15 \\
\hline & \multicolumn{5}{|c|}{ Poplars and willows } \\
\hline Populus nigra & $\mathrm{X}$ & $\mathrm{CA}^{\mathrm{c}}$ & & & 86 \\
\hline Populus sp. & $\mathrm{X}$ & $\mathrm{CA}^{\mathrm{c}}$ & 2 & 4.50 & 54 \\
\hline Salix sp. & $\mathrm{X}$ & $\mathrm{CA}^{\mathrm{c}}$ & & & 81 \\
\hline Total & & & 50 & 114.85 & \\
\hline
\end{tabular}

aprovenances trial/families; ${ }^{\text {c}}$ clonal seed orchard; ${ }^{\mathrm{c}}$ clonal archive.

\section{Conservation of Conifer Genetic Resources}

\subsection{Black Pine (Pinus nigra)}

Black Pine (Pinus nigra) is endangered Mediterranean forest species for which it is necessary to undertake measures to preserve their genetic diversity. Some initial research has been carried out which will help in the planning of measures for its conservation. Special emphasis is placed on the endemic subspecies ( $P$. nigra ssp. dalmatica). In Croatia, three subspecies of Black Pine grow naturally: subsp. nigra, subsp. dalmatica, and subsp. illyrica. Research on the genetic variability has been done and results showed that the investigated populations are divided into two groups, both differing from the representatives of the typical subspecies. The first group con- 


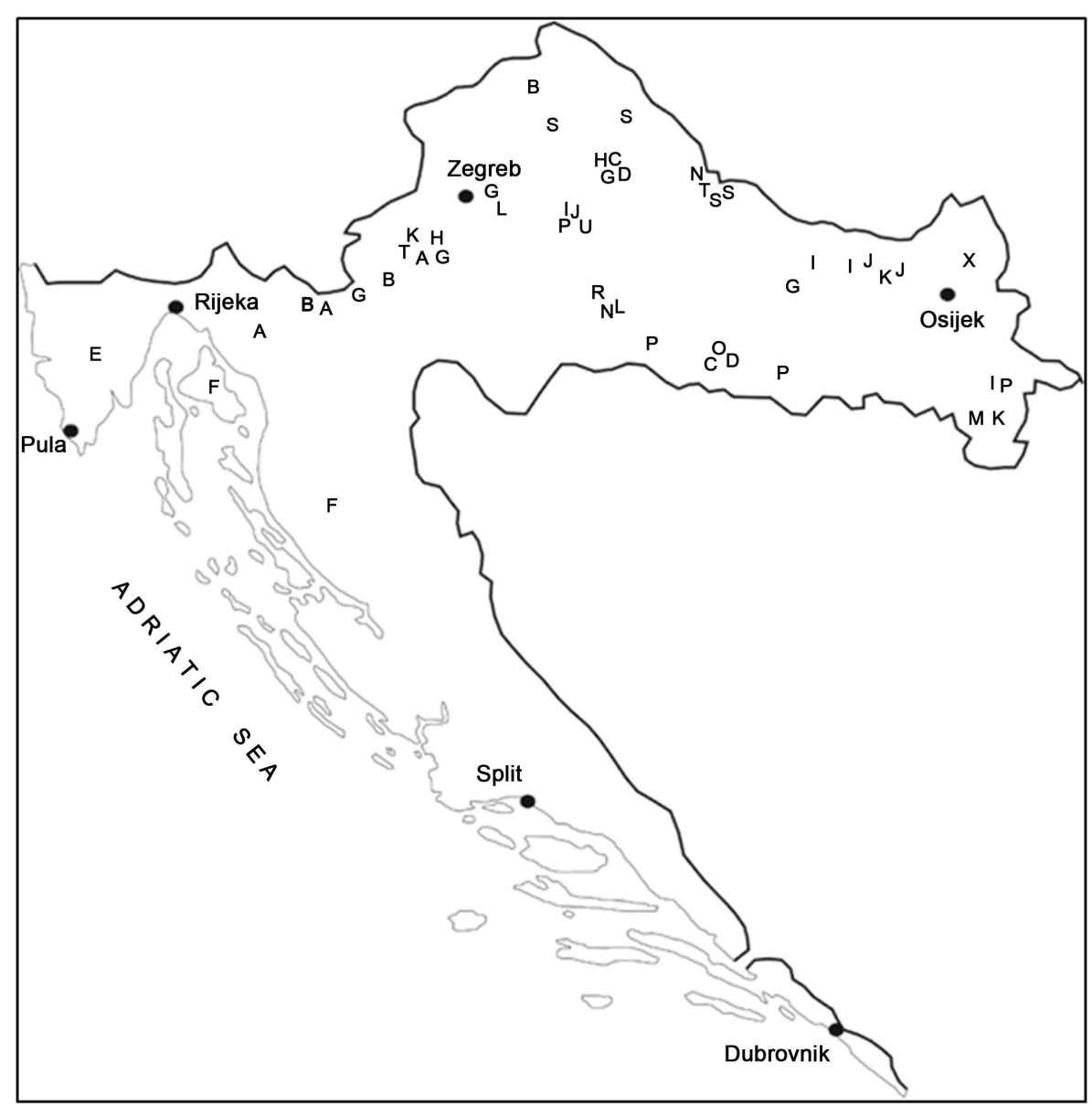

Figure 1. Distribution of location of ex situ objects.

sisted of the insular populations of islands Brač, Hvar and Korčula (subsp. dalmatica), while the second group included the continental populations (subsp. illyrica). One population from Pelješac was classified as a transitory one between the subspecies dalmatica and illyrica (Liber et al., 2002; Liber et al., 2003). Stenoendemic subspecies of the Dalmatian black pine has been reduced to several populations only, and there are some signs of continuous diminishing of its range and its need of making an action plan to preserve all natural populations of this subspecies.

The previous results included assumptions on the negative processes that threaten the genetic diversity of the Black Pine in Croatia. It is clear that a strong discontinuity of the distribution and a small effective size of natural populations point to the real possibility that the formation of the genetic structure of the Black Pine is affected by genetic drift and inbreeding, with all the negative consequences and with the additional biotic and abiotic factors negatively affect the genetic diversity.

Plantations of the Black Pine established with the plant material of unknown origin or that originating from geographically distant provenances and/or different subspecies also present a threat to the genetic diversity. This phenomenon could result in considerable mixing of gene groups of domestic and foreign populations, i.e. the "genetic pollution" of domestic natural populations. Pests also contribute to endangering the genetic diversity by reducing the size of the populations and the vitality and fertility of the trees.

Considering the spread of the Black Pine in the Mediterranean region and the global climate change in terms of warming and the reduction of precipitation, it is evident that forest fires present factors that devastate the genetic diversity of the species. Bearing in mind the size of the subsp. dalmatica Black Pine population in Croatia, there is a real possibility that a single major fire can cause the complete extinction of individual natural populations, while the continuous impact of smaller fires could cause considerable reductions of genetic diversity.

Two Black Pine clonal seed orchards with progeny trials was established in 1992 and 2006 and further research 
should include the selection of the half-sib families, in order to establish an improved clonal seed orchard. The strategy for the preservation of genetic diversity of the Dalmatian Black Pine endemic populations in Croatia should be developed by applying in situ and ex situ methods. In practice, this means that at the very beginning sampling of a sufficient number of trees should be made in the existing natural population. From these trees, seed should be collected and a progeny raised for establishing ex situ conservation populations (tests of populations and families obtained by free pollination). The second step should be to sample a sufficient number of trees in the natural populations for vegetative reproduction and for the establishment of ex situ conservation clonal seed orchard.

The establishment and careful maintenance of the clonal seed orchards (with the maintenance of the previously established progeny tests) would create all the prerequisites for the long-term preservation of the genetic resources of the Dalmatian Black Pine populations. While implementing the practical conservation measures, it is necessary to establish permanent research monitoring aimed at studying the existing genetic structures as thoroughly as possible, and monitoring the further genetic processes both in the natural and conservational populations. Such monitoring would enable the already taken measures to be evaluated, and would serve as the basis for making decisions on additional efforts for the conservation of the genetic resources.

\subsection{Silver Fir (Abies alba)}

Dieback of Silver Fir in Croatia, especially in Dinaric part, is associated with complex changeable effects of abiotic and biotic factors. The dieback was recorded at all expositions, terrain slopes and altitudes, as well as in all forest associations. At the border of its natural range, relief, climate and structural factors have dominant effects on tree dieback, while in the central part of Gorski Kotar climatic factors have dominant effect (Potočić et al., 2005; Tikvić et al., 2008; Ugarković et al., 2011).

Initial research on variability and growing success of various provenances of Silver Fir in Croatia started during the 1990's and results showed significant statistical differences among the provenances (Ivanković et al., 2007). Provenance trial was established with eighteen Croatian and two neighbouring Slovenian provenances and one of traits that were measured was number of lateral buds on terminal sprout and late frost damage to newly formed shoots on seedlings. Results showed that number of lateral buds differs significantly between the years of observation and significant difference was determined among provenances and interaction year $\times$ provenance. Damage from the late frost was not equal in all provenances but provenance showed grouping in three distinct groups. There was no significant correlation between frost damage to young sprouts and altitude of origin of provenance (Ivanković et al., 2006; Ivanković et al., 2007; Ivanković et al., 2008). For all the studied traits, significant statistical differences for age $\times$ provenance interaction were obtained, while the late frost damage proved to affect the number of lateral buds. Certain provenances showed general adaptation, i.e. phenotypical stability, while certain provenances were phenotypicaly unstable, indicating specific adaptation to a particular habitat.

Research based on genetic and molecular analysis of the nad 5 - 4 gene has confirmed the existence of haplotype 1 in Croatian provenances, normally characteristic for Central and Western Europe, as well as of haplotype 2, characteristic for the Southeast Europe (Ivanković, 2007).

\section{Conservation of Social Broadleaves Genetic Resources}

\subsection{Pedunculate Oak (Quercus robur)}

Pedunculate Oak has the greatest and most continuous distribution range compared to other forest tree species found in wet and floodplain forests. This is an anemophilic species, thus showing a significant ability of gene migration to great distances in both time and space. Gene migrations to greater distances by means of seed dispersal are rather improbable, but it is supposed that human activity has significantly enhanced such dispersion. Pedunculate Oak grows in diverse habitat conditions (in terms of phytocoenoses, soil, water regime, climatic characteristcs), which could have a diverse impact on genetic structure of natural populations, by means of natural selection. Genetic diversity within and among Pedunculate Oak natural populations in Croatia has not been deeply studied, but, based on initial studies and taking into consideration biological and ecological traits and management, a high rate of intrapopulation variability with a small intrapopulation differention can be assumed.

Selection of plus trees of Pedunculate Oak and establishment of clonal seed orchards have been carried out in accordance with the prior scientific knowledge. The assumption is that the seed orchards make an appropriate base 
for the ex situ conservation of genetic variability of the species, as well as production base of quality seed intended for regeneration of oak stands. It is assumed that the offspring of the selected plus trees holds superiority over the offspring of average trees from natural stands. The statement is yet to be confirmed by research of the existing progeny trials. Interclonal variations in flushing phenology were observed (early and late forms). Most likely, the early forms possess greater resistance to late frosts; a information that could prove important for further research and practice.

Research conducted on genetic variability of quantitative traits of pedunculate oak originated from limited distribution area (Krstinić et al., 1996; Franjić et al., 2000; Bogdan et al., 2004), showed a high rate of intrapopulation variability and a lack of interpopulation differentiation for the traits of growth. Certain grouping of the studied population was recorded for the number and size of the stomata. Research on the possilibility for breeding showed a significant share of additive genetic variance, high rate of heritability, as well as a considerable genetic gain for height at an early age (Vidaković et al., 2000).

Three open pollinated progeny trials of Pedunculate Oak plus trees have been established, representing three seed regions. Based on that assumption it could be speculated that high additive variability for heights results from significant individual variabilities for flushing traits in selected plus trees and ecotypical differentiation of their original populations results with significant individual genetic variability in two out of three seed regions (Kajba et al., 2011). High values of additive coefficients of variation suggest wide genetic variability of selected plus trees and good adaptability of their progeny to changing environmental conditions. In all trials the estimated expected genetic gains by backward selection among first generation plus trees after open-pollinated progeny testing showed the highest values.

In accordance with the delineation of Regions of Provenances of forests in Croatia into ecogeographic seed regions and zones three clonal seed orchards of Pedunculate Oak (Quercus robur), have been established. Phenotypical selection and heterovegetative propagation of plus trees, as well as the establishment of clonal seed orchards were launched with the goal of controlling more regular yield periodicity and obtaining forest seed of good genetic quality of forest reproductive material in the categories Qualified and Tested. The orchards are regularly subjected to pomotechnical treatments, protection and other measures of maintance (Kajba et al., 2007). Establishment and evaluation of progeny trials are provided for all of three clonal seed orchards. Genetic diversity within and between clonal seed orchards was analysed with two type of molecular microsatellite markers; nuclear and chloroplast (Katičić Bogdan, 2012). Results have shown that nuclear microsatellites do not differentiate genetically between clonal seed orchards i.e. between seed regions they represent. There was also no genetic differentiation found with nuclear microsatellites between phenological forms or haplotypic lineages.

\subsection{European Beech (Fagus sylvatica)}

European Beech (Fagus sylvatica L.) is one of the most important and widely distributed tree species in Croatia. It covers $47 \%$ of the total forest area and makes $45 \%$ of the entire growing stock. European Beech is one of the main European forest tree species in terms of its ecological and economical value. It has survived highly intensive climatic and geological changes during Quaternary, because some populations were known to have occurred in the areas not affected by glaciation. These populations represent the origins of the species as it is known today.

European Beech is considered as the most vital tree species in Croatia and there is not any significant damages in the beech stands caused by pests or diseases (Ivanković et al., 2010). Defoliation status of the beech in Croatia showed that severe damage varied between $4.2 \%$ and $11.9 \%$, which was lower than in the rest of the Europe (Potočić \& Seletković, 2000). No continuity was found in the deterioration of the condition of the beech in any of the damage classes. It fluctuated, depending on the strength of diverse unfavourable ecological and biological factors. Comparing common provenances in the Croatian and Slovenian trial it was observed that some provenances showed phenotypic stability under different site conditions, while some provenances showed specific adaptability. Studies unfertaken on growth traits and flushing phenology in European provenance trial in Croatia indicate ecotypic pattern of genetic diversity (Jazbec et al., 2007).

Research on the growth of various provenances of European beech in Croatia started at the beginning of the 1990s and the continued by the 2005 taking part in internationally conducted projects (e.g. COST Action E52 Project, 2010). The first results regarding growth success in a field trial showed considerable genetic differenttiation among the provenances, as well as within provenance variability (for traits such as survival rate, plant height, and flushing). Survival rates and average plant heights of European Beech provenances were higher from 
the areas of Croatia, Slovenia and Ukraine, than from the other countries. Differences in flushing among the provenances are clearly visible, with local provenances showing earlier flushing than the foreign ones. The first results obtained by monitoring of the survival rate, height increment, and phenotypical traits have shown that such studies should be continued as to evaluate growth success and genetic variability of native and foreign provenances, as well as to determine total genetic variability of European Beech, together with the provenance $\times$ site interaction. It is most likely that population differentiation in South-East Europe has ecotypic pattern that is shaped by macroclimatic adaptation (Mátyás et al., 2009; Ivanković et al., 2011). It can be recommended than European Beech seed zone delineation and use of its forest reproductive material should be done accordingly to ecological besides the geographic criteria.

\section{Conservation of Noble Hardwood Genetic Resources}

\subsection{Narrowleaf Ash (Fraxinus angustifolia)}

In Croatia, Narrowleaf Ash is distributed in the Pannonian lowland area, along the banks of the rivers Drava, Danube, and Sava, as well as their tributaries. In the Submediterranean area, it stretches from Istria and Hrvatsko primorje, and, along the Dalmatian rivers, to Slano near Dubrovnik (Fukarek, 1954, 1987). Studies of genetic variability of the species have recently started. Narrowleaf Ash is an anemophilic species, with a capacity for seed distribution to great distances. Considering its distribution range, it can be assumed that the greatest share portion of its genetic variability (on an individual level, i.e. within the population) is localized through Sava river region, while the overall population differention is probably rather small (strong impact of gene migrations, reducing differentiation among the populations). On the other hand, the assumption is that the populations and trees pertaining to the Mediterranean region are very much affected by genetic drift (small isolated populations, groups or individual trees), and therefore endangered in terms of conservation of the species genetic diversity. According to Fukarek (1954) Narrowleaf Ash from the Mediterranean region of Croatia is taxonomically a subspecies (subsp. angustifolia), thus differing from the continental populations (subsp. oxycarpa).

In order to test the above assumptions, four provenance and open progeny trials were established. It comprises 90 open pollinated families from 11 natural populations, representing a greater part of the Narrowleaf Ash distribution range in Croatia. Thus designed trials enable research on genetic variability of the adaptive traits, quantitative traits with economic value (quality of stemwood, straightness, forking, etc.), as well of the neutral traits (biochemical and DNA markers). The ongoing research in trials with populations originating from the Sava river valley confirms the previously mentioned hypotheses about significant within population genetic variability, with lack of interpopulational differentiation (Bogdan et al., 2005). Further work on the given groups of traits in trials will answer the question on the character and degree of genetic variability of Narrowleaf Ash in greater part of its natural distribution area in Croatia. The obtained results will serve as a foundation for the scientifically based planning of genetic resources conservation and forest tree breeding.

In Croatia Fraxinus angustifolia is widely distributed in the Pannonian lowland area. In this area we have established two clonal seed orchards. Through the period of three years the phenological differences have been observed in monitoring of six flushing phases on which was based strategy to determine interclonal and intraclonal discrepancies and variations. In this period seed orchards where continuously monitored and checked for the presence of Chalara fraxinea, but it was not confirmed, and on the ramets there were no simptoms that would indicate its presence (Milotić et al., 2013). With the results gathered from this monitoring we where able to determine and classify clones into early and late flushing groups, which has a high practical value not only for seed orchard protection and maintaining the high vitality of the clones, but also for the distribution and application of seed from the seed orchard.

\subsection{Wild Cherry (Prunus avium) and Field Elm (Ulmus minor)}

Conservation of genetic diversity of forest trees, especially those highly endangered species, represented only by individual trees or groups of trees (as is the case with Field Elm and Wild Cherry), is the prerogative when we talk about maintaining of at least a part of their evolution formed adaptation potential, and ensuring of their genetic regeneration. In order to encompass the still existing genetic variability of these highly endangered species, their conservation is to be conducted by using the ex situ methods-by establishing of clonal archives and clonal seed orchards. Wild Cherry genotypes from the clonal seed orchard was taken for the investigation of genetic vari- 
ability of selected plus trees from the area of north-western Croatia. The clones were analyzed by 15 selected microsatellite markers (SSR), chosen by the ECPGR. A wealth of allelic variations was found in SSR loci, while a high degree of polymorphism confirmed the existence not only of extensive morphological but also a very significant genetic diversity (Tančeva Crmarić et al., 2011). The analysis of molecular variance revealed a significantly higher percentage (95.88\%) of the total microsatellite diversity caused by the differences among the invidividuals within the regions, compared to that caused by the differences between the studied regions (4.12\%) and indicates the existence of specific regional structurality of genetic diversity.

Among others, priority list for conservation of the genetic resources especially specifies Field Elm (Ulmus minor), an economically and ecologically valuable tree species, now nearly extinguished from both our and European lowland forest ecosystems, having been affected by Ophiostoma ulmi and Ophiostoma novo-ulmi diseases. Once established, the Field Elm clonal archive has ensured preservation of the remaining old elm trees from the whole of Croatia, aiming for the selection of clones tolerant to these diseases. Clonal archive of the selected adult trees of Field Elm consists of 50 clones and 252 ramets. This species grows in very different ecological conditions and it is assumed that populations, especially the ones from climatically contrasting and geographically remote stands, differ from each other. Changes in water relations and tree dieback in lowland forest ecosystems had drastic negative impact on biodiversity and as a consequence the Field Elm is threatened by negative human impacts and by Dutch Elm Disease. There were significant differences in morphometric variability among trees within populations and among populations (Zebec et al., 2010).

\section{Conservation of Poplar and Willow Genetic Resources}

In Croatia, European Black Poplar (Populus nigra) grows in riparian forests along the rivers Mura, Sava, Drava and the Danube. It occupies small share portion within the total forest area, but is significant for its general use. Constant human intervention into natural habitats of European Black Poplar has reduced its distribution area size to separate, partially isolated areas, although, in European terms, these are well preserved riparian forests. Population regeneration of this species represents a highly important task of silvicultural treatment, most notably in the areas where these riparian habitats and ecosystems are endangered. Restored or preserved populations of poplar represent a vital contribution in conservation of a complex ecosystem of the riparian forest. The basic aim of genetic resources conservation is to preserve genetic potential for adaptation of the species and its populations through a prolonged period of time, enabling the course of their evolution, but having in mind habitat changes.

Thus, the idea is to intensify selection, reproduction and testing of native Black Poplar clones, so as to obtain quality forest reproductive material intended for is regeneration of the riparian forest stands. Moreover, selection of plus trees from younger populations of European Black Poplar is needed, thus making possible the selection of the new genotypes, well adapted to specific local habitats (Kajba et al., 2005).

Regeneration strategy is to be guided by the principle of substitution of the plantations of $P$. $\times$ canadensis hybrid poplar with European Black Poplar, but, in accordance with the plan of silvicultural management. This plan should carefully pinpoint habitats characterized with water regime that is suitable for growing of poplar trees, regeneration methodology, and activity dynamics. A period of at least 50 years should be set for fulfilling of this goal-a complete substitution of stands (Kajba et al., 2004).

Ideally, only units intended for conservation should be more or less isolated from poplar plantations. Other areas are to be prepared in a way so as to resemble habitat conditions of the Euro-American poplar. When conservation and protected parts are concerned, there is no need to completely avoid or exterminate poplar culture, especially if the population is big enough. For the restored population, a so called buffer zone can be used around the plantation (with the trees from a local population, and the same share portion of trees from both sexes). Monitoring of the rate of introgression in the protected compartments should be implemented. This strategy should evaluate the rate of introgression in today's adult trees and make comparison with possible introgression in the next generation, after it has reached physiological maturity of flowers. The population has to be big enough in order to avoid genetic drift (accidental loss of gene varieties caused by stochastic processes) and its impact upon genetic diversity and a share of inbreeding. Furthermore, a small population will show a higher degree of fixation of certain alleles in the successive generation (Lefèvre et al., 2001). In two clonal archives of European Black Poplar and one Salicetum total number of 101 clones of poplars are present. This clonal archives will be gradually expanded with the new clones of European Black Poplar, through selection of the old trees, or by inclusion of the clones currently in reproduction in the nurseries. 
Natural populations of willows are discontinuously and longitudinally spread along the Danube and Drava river. Through these populations, along with some smaller isolated areas around the Mura and the Sava rivers, conservation of genetic diversity of willows in the area of Croatia has been ensured. Clonal archives and clonal tests contain more than 250 clones of different willow species and hybrids, most of which belong to the species Salix alba. Clones of the Salix alba species and hybrids Salix $\times$ viridis and S. $\times$ rubens were selected in local populations in the area of the Danube, Sava and Drava rivers. Together with the indigenous clones, a certain number of exotic willow clones is available, all making genetically diverse planting stock. The existence of genetic divergence in cultivated clones of White Willow and its hybrids has enabled secondary selection of genotypes, showing specific adaptation to optimal habitats, as well of those with specific adaptation to atypical habitats for willow, e.g. oak habitats in the lowland flooded forests along the Sava river (Kajba et al., 2006). Such genotypes are of particular importance for degraded and wasteland areas of the lowland forests, for the purpose of an easier restoration of the more valuable forest species, primarily those of Narrowleaf Ash (Fraxinus angustifolia), Pedunculate Oak (Quercus robur) and Field Elm (Ulmus minor).

\section{Conclusions}

Genetic conservation of forest trees represents maintenance of the evolutionary created adaptation potential of a species, and therefore, its forest community, and the entire ecosystem. For the purpose of the conservation of the forest tree species, protection is needed of the existing genetic variability, its adaptability to processes of evolution and breeding. Our knowledge should be improved and identification of individuals tolerant to certain pests and diseases, making sure that decrease in the size of genetic resources of the endangered species has been avoided.

Research should be supplemented by data encompassing forest inventory, legislation, pratical utilization, coordination on both national and pan-European levels, as well as promotion of public awareness on the importance of the conservation of the endangered species pertaining to the forest ecosystems. Conservation of genetic diversity of various forest tree species is conducted through programmes making use of the in situ and ex situ methods.

In Croatia, a total of 125 seed stands have been selected, covering a total of 3885.53 ha. Clonal seed orchards are also a nucleus of conservation of forest genetic resource using the ex situ statistical method, since the relationship between the size of population and the percentage of preserved heterozygosity is thus reduced to minimal loss of total additive genetic variability. Climate changes and new habitat conditions will pose additional challenges to forest reproductive material and forest management; in turn, this will influence their economic and social benefits, as well as biological diversity of forest ecosystems. By the ex situ method, a total of 50 different types of field plots were established (provenance and progeny trials, clonal seed orchards, clonal archives) covering the area of 114.85 ha.

\section{References}

Act on Forest Reproductive Material (2009)

http://faolex.fao.org/cgibin/faolex.exe?rec_id=076788\&database=faolex\&search_type=link\&table=result\&lang=eng\&for mat name=@ERALL

Bogdan, S., Katičić-Trupčević, I., \& Kajba, D. (2004). Genetic Variation in Growth Traits in a Quercus robur L. OpenPollinated Progeny Test of the Slavonian Provenance. Silvae Genetica, 53, 198-201.

COST Action E52 Project (2010). Evaluation of Beech Genetic Resources for Sustainable Forestry. http://www.bfafh.de/inst2/cost e52/cost e52.htm

Council Directive 1999/105/EC of 22 December 1999 on the Marketing of Forest Reproductive Material. Official Journal L 011 (15/01/2000), 17-40. http://www.europa.eu.int/eur-lex/en/lif/dat/1999/en_399L0105.html

Eriksson, G., Ekberg, I., \& Clapham, D. (2013). An Introduction to Forest Genetics. Uppsala: SLU.

Forest Law (2005). http://narodnenovine.nn.hr/clanci/sluzbeni/2005 11140 2642.html

Forest Law (2006). http://narodnenovine.nn.hr/clanci/sluzbeni/2006_07_82_1964.html

Forest Law (2008). http://narodnenovine.nn.hr/clanci/sluzbeni/2008_11_129_3681.html

Forest Stewardship Council (2012). https://us.fsc.org/

Geburek, T., \& Turok, J. (Eds.) (2005). Conservation and Management of Forest Genetic Resources in Europe. Zvolen: Arbora Publishers. 
Ivanković, M. (2007). Possibility of Nordmannn Fir (Abies nordmaniana Steven) Genes Introgression in to Silver Fir (Abies alba Mill.) Forest in Macelj and Trakošćan. Šumarski List, 131, 529-538.

http://www.sumari.hr/sumlist/radovi.asp?gb=B200705290

Ivanković, M., Bogdan, S., Gračan, J., \& Bogdan, S. (2010). Current Status of European Beech (Fagus sylvatica L.) Genetic Resources in Croatia. Communicationes Instituti Forestalis Bohemicae, 25, 70-77.

Ivanković, M., Bogdan, S., Marjanović, H., Kajba, D., \& Gračan, J. (2006). Growth and Development Dynamics of Terminal Sprout of Silver Fir (Abies alba Mill.) on Plants in Provenance Trials in Croatia. Radovi Šumarskog instituta, 41, 17-24.

Ivanković, M., Marjanović, H., Franjić, J., Škvorc, Ž., \& Bogdan, S. (2007). Variability of Silver Fir (Abies alba Mill.) Provenances in Number of Lateral Buds on the Terminal Sprout and Damage by the Late Frost. Periodicum Biologorum, 1, 55-59.

Ivanković, M., Popović, M., Katičić, I., von Wuehlisch, G., \& Bogdan, S. (2011). Quantitative Genetic Variation of European Beech (Fagus sylvatica L.) Provenances from the Southeastern Europe. Šumarski list posebni broj, 25-37. http://www.sumari.hr/sumlist/pdf/201150250.pdf

Ivanković, M., Punek, I., Littvay, T., Perić, S., \& Marjanović, H. (2008). Application of Survival Analysis in the Research of Variability of Foliation of European Fir (Abies alba Mill.) Provenances. Radovi Šumarskog Instituta, 1, 19-30.

Jazbec, A., Šegotić, K., Ivanković, M., Marjanović, H., \& Perić, S. (2007). Ranking of European Beech Provenances in Croatia Using Statistical Analysis and Analytical Hierarchy Process. Forestry, 80, 151-162. http://dx.doi.org/10.1093/forestry/cpm007

Kajba, D., Gračan, J., Ivanković, M., Bogdan, S., Gradečki-Poštenjak, M., Littvay, T., \& Katičić, I. (2006). Conservation of Forest Genetic Resources in Croatia. Glasnik za šumske pokuse posebno izdanje, 5, 235-249.

Kajba, D., Katičić, I., \& Bogdan, S. (2011). Estimation of Genetic Parameters in Open Pollinated Progeny Trials from Plus Trees of Pedunculate Oak (Quercus robur L.) Selected in Posavina, Podravina and Podunavlje Seed Zones. Croatian Journal of Forest Engineering, 32, 177-192.

Kajba, D., Pavičić, N., Bogdan, S., \& Katičić, I. (2007). Pomotechnical Treatments in the Broadleave Clonal Seed Orchards. Šumarski List, 11-12, 523-528. http://www.sumari.hr/sumlist/radovi.asp?gb=B200705230

Katičić Bogdan, I. (2012). Genetic Diversity of Pedunculate Oak (Quercus robur L.) in Croatia. Ph.D. Thesis, Zagreb: Zagreb University.

Koskela, J., Buck, A., \& Teissier Du Cros, E. (Eds.) (2007). Climate Change and Forest Genetic Diversity: Implications for Sustainable Forest Management in Europe. Rome: Bioversity International. http://www.euforgen.org/fileadmin/bioversity/publications/pdfs/1216.pdf

Lefèvre, F., Barsoum, N., Heinze, B., Kajba, D., Rotach, P., de Vries, S. M. G., \& Turok, J. (2001). EUFORGEN Technical Bulletin: In Situ Conservation of Populus nigra. Rome: International Plant Genetic Resources Institute. http://www.euforgen.org/fileadmin/bioversity/publications/pdfs/741_In_situ_conservation_of_Populus_nigra.pdf

Liber, Z., Nikolić, T., \& Mitić, B. (2002). Intra- and Interpopulation Relationships and Taxonomic Status of Pinus nigra Arnold in Croatia According to Morphology and Anatomy of Needles. Acta Societatis Botanicorum Poloniae, 71, $141-147$. http://dx.doi.org/10.5586/asbp.2002.016

Liber, Z., Nikolić, T., Mitić, B., \& Šatović, Z. (2003). RAPD Markers and Black Pine (Pinus nigra Arnold) Intraspecies Taxonomy-Evidence from the Study of Nine Populations. Acta Societatis Botanicorum Poloniae, 72, $249-257$. http://dx.doi.org/10.5586/asbp.2003.033

Mátyás, C., Božić, G., Gömöry, M., Ivanković, M., \& Rasztovics, E. (2009). Transfer Analysis of Provenance Trials Reveals Macroclimatic Adaptdness of European Beech (Fagus sylvatica L.). Acta Silvatica Lignaria Hungarica, 5, 47-62.

Milotić, M., Kajba, D., \& Diminić, D. (2013). Phenological Differences in Clonal Seed Orchards of Non-Infected Narrow Leaf Ash (Fraxinus angustifolia Vahl) with Chalara fraxinea. 4th Meeting \& Workshop "Froniers in Ash Dieback Research”, Malmö, 4-6 September 2013, 24 p.

National Forestry Strategy and Policy (2003). Nacionalna šumarska politika i strategija. http://narodne-novine.nn.hr/clanci/sluzbeni/2003_07_120_1663.html

Potočić, N., Ćosić, T., \& Pilaš, I. (2005). The Influence of Climate and Soil Properties on Calcium Nutrition and Vitality of Silver Fir (Abies alba Mill.). Environmental Pollution, 137, 596-602. http://dx.doi.org/10.1016/j.envpol.2005.01.045

Tančeva Crmarić, O., Štambuk, S., Šatović, Z., \& Kajba, D. (2011). Genotypic Diversity of Wild Cherry (Prunus avium L.) in the Part of Its Natural DISTRIBUTION in Croatia. Šumarski List, 135, 543-555.

Tikvić, I., Seletković, Z., Ugarković, D., Posavec, S., \& Španjol, Ž. (2008). Dieback of Silver Fir (Abies alba Mill.) on Northern Velebit (Croatia). Periodicum Biologorum, 110, 137-143.

Ugarković, D., Tikvić, I., \& Seletković, Z. (2011). Correlation of Habitat and Structural Factors with Dieback and Nutrition of Silver Fir (Abies alba Mill.) in Gorski Kotar. Croatian Journal of Forest Engineering, 32, 57-71. 
Vidaković, M., Kajba, D., Bogdan, S., Podnar, V., \& Bećarević, J. (2000). Estimation of Genetic Gain in a Progeny Trial of Pedunculate Oak (Quercus robur L.). Glasnik za šumske pokuse, 37, 375-381.

Zebec, M., Idžojtić, M., Poljak, I., \& Mihaldinec, I. (2010). The Variability of Field Elm (Ulmus minor Mill. sensu latissimo) in Croatia Drava Valley According to the Leaf Morphology. Šumarski List, 134, 569-580.

http://www.sumari.hr/sumlist/pdf/201005690.pdf 
Scientific Research Publishing (SCIRP) is one of the largest Open Access journal publishers. It is currently publishing more than 200 open access, online, peer-reviewed journals covering a wide range of academic disciplines. SCIRP serves the worldwide academic communities and contributes to the progress and application of science with its publication.

Other selected journals from SCIRP are listed as below. Submit your manuscript to us via either submit@scirp.org or Online Submission Portal.
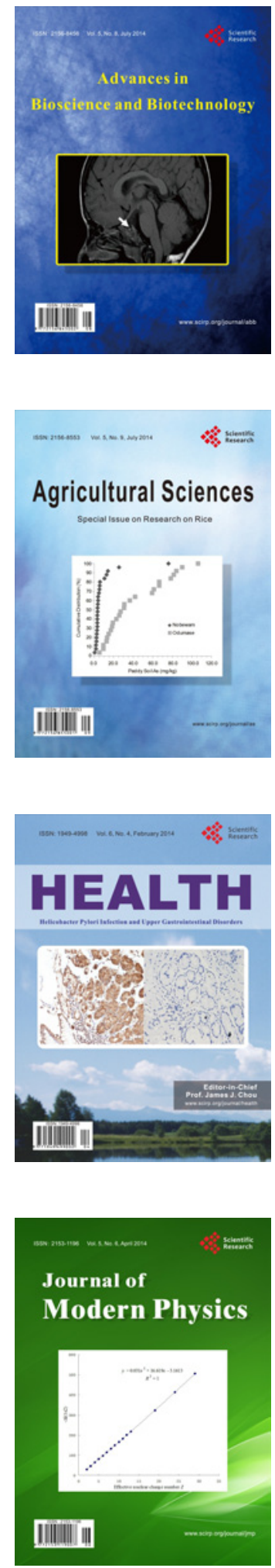
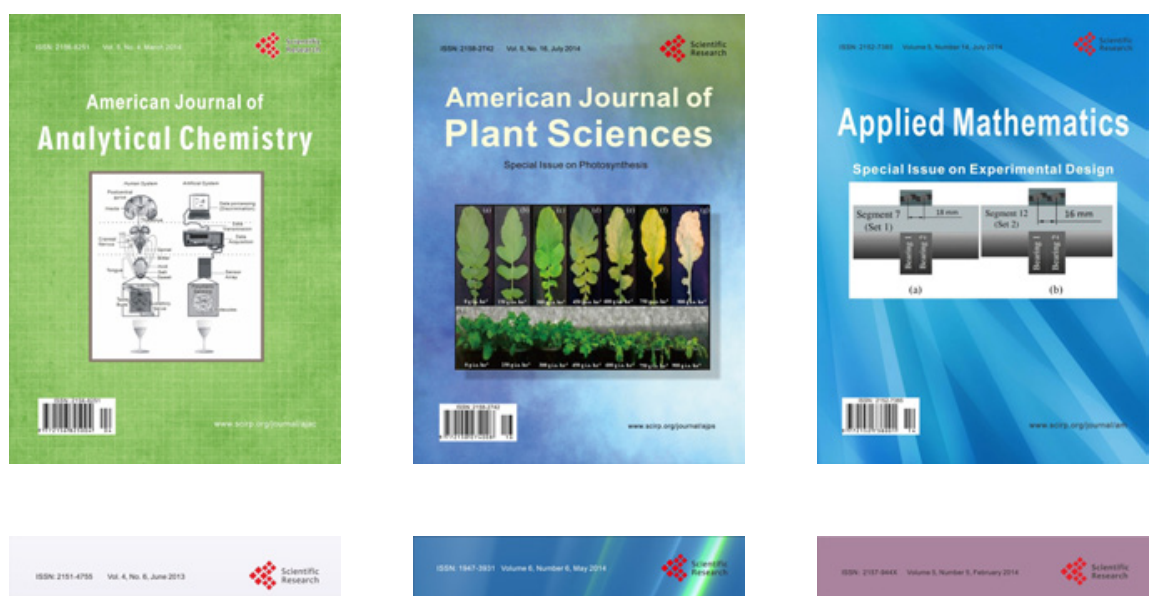

Creative Education
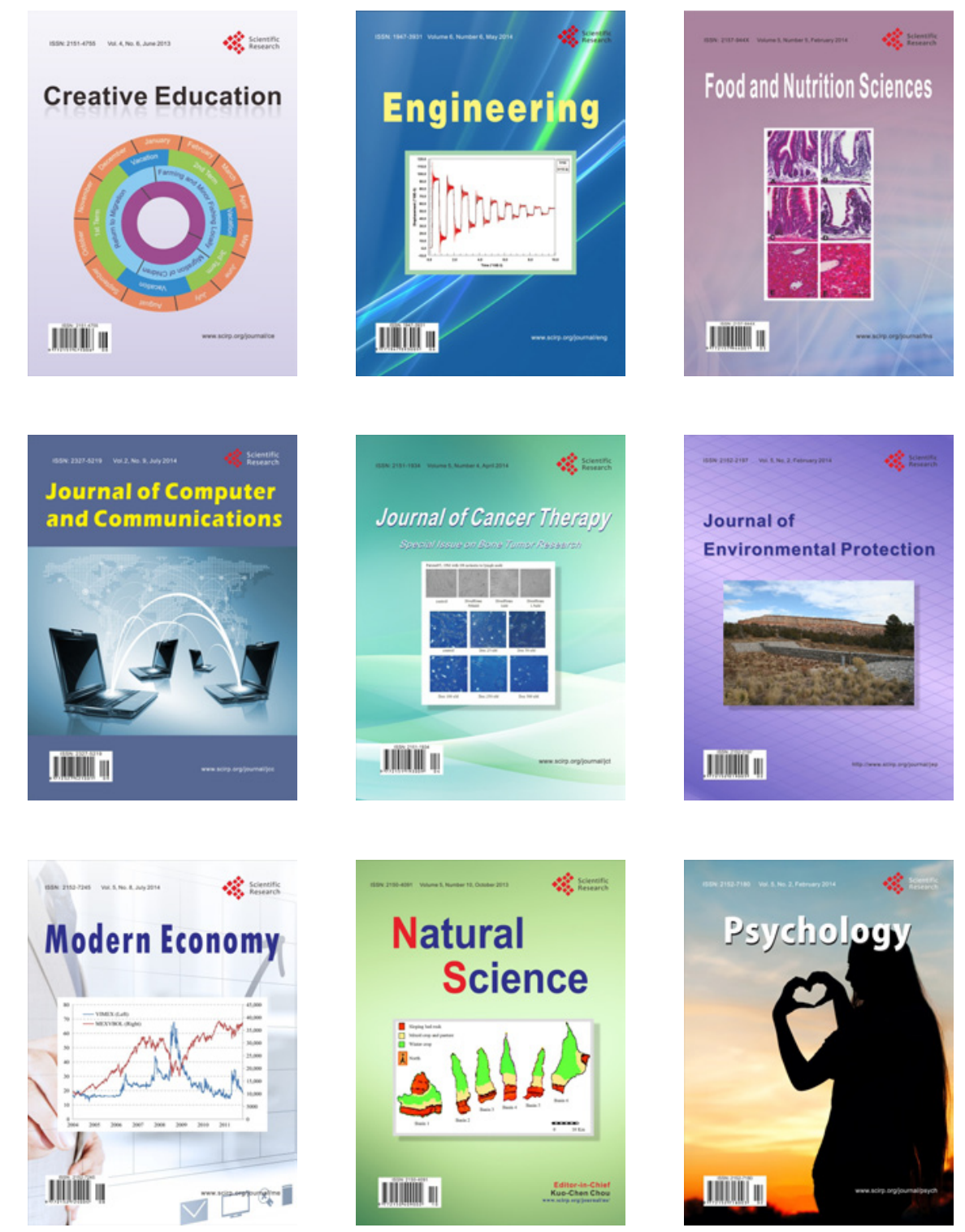